\title{
Diagnosis and molecular characterization of rabies virus from a buffalo in China: a case report
}

Ke-shan Zhang ${ }^{1,2+}$, Jian-hong Guo ${ }^{1+}$, Zhuo-fei Xu², Min Xiang ${ }^{2}$, Bin Wu ${ }^{2 *}$, Huan-chun Chen ${ }^{2}$

\begin{abstract}
Background: Rabies virus (RABV) can infect many different species of warm-blooded animals. Glycoprotein G plays a key role in viral pathogenicity and neurotropism, and includes antigenic domains that are responsible for membrane fusion and host cell receptor recognition.

Case presentation: A case of buffalo rabies in China was diagnosed by direct fluorescent antibody test, $G$ gene reverse-transcriptase polymerase chain reaction, and RABV mouse inoculation test. Molecular characterization of the RABV was performed using DNA sequencing, phylogenetic analysis and amino acid sequence comparison based on the $\mathrm{G}$ gene from different species of animals.

Conclusion: The results confirmed that the buffalo with suspected rabies was infected by RABV, which was genetically closely related to HNC (FJ602451) that was isolated from cattle in China in 2007. Comparison of the G gene among different species of animal showed that there were almost no amino acid changes among RABVs isolated from the same species of animals that distributed in a near region. However, there were many changes among RABVs that were isolated from different species of animal, or the same species from different geographic regions. This is believed to be the first case report of buffalo rabies in China, and the results may provide further information to understand the mechanism by which RABV breaks through the species barrier.
\end{abstract}

\section{Background}

Rabies virus (RABV) is one of the seven species in the genus Lyssavirus in the Rhabdoviridae family [1]. All warm-blooded animals, including raccoons, skunks, bats and foxes, are susceptible to RABV, and domestic dogs act as the main reservoir and transmitter [2]. The annual number of human deaths caused by rabies is estimated to be 55,000 worldwide [3], with about 32,000 in Asia [4]. The total number of human deaths was 108,412 between 1950 and 2004 in China [5]. The average number was 1,524 from 1996 to 2008 , and $50 \%$ of cases were reported in Guangxi, Hunan and Guizhou provinces [6]. Therefore, the disease continues to be a serious public and animal health problem in China.

RABV has a non-segmented, negative-sense, singlestranded RNA genome about $12 \mathrm{~kb}$ in length [7], with five genes: L (RNA polymerase), G (glycoprotein), M

\footnotetext{
* Correspondence: wub@mail.hzau.edu.cn

+ Contributed equally

${ }^{2}$ State Key Laboratory of Agricultural Microbiology, College of Veterinary

Medicine, Huazhong Agricultural University, Wuhan 430070, Hubei, PR China Full list of author information is available at the end of the article
}

(matrix protein), $\mathrm{P}$ (phosphoprotein), and $\mathrm{N}$ (nucleoprotein) [8]. The order of relative conservation of these five genes from high to low could be either $\mathrm{N}>\mathrm{L}>\mathrm{M}>\mathrm{P}>\mathrm{G}$, or $\mathrm{N}>\mathrm{L}>\mathrm{M}>\mathrm{G}>\mathrm{P}$ [9]. Glycoprotein $\mathrm{G}$ of RABV plays an important role in pathogenicity $[10,11]$ and viral neurotropism [12] because it contains membrane fusion sites [13] and host cell receptor domains [14,15]. In recent years, molecular epidemiology [16-18] and diagnosis $[19,20]$ of rabies have been based on the $G$ gene.

The aims of the present study were to diagnose a case of buffalo rabies that occurred in Wuhan City, Hubei Province, using three different methods, and to compare the sequences with different RABVs that were isolated from different species, based on the $G$ gene. This is believed to be the first report of the phylogenetic analysis of buffalo RABV in China compared with other isolates from different animals.

\section{Case presentation}

Specimens were collected from the gyrus hippocampi of the buffalo with suspected rabies in Wuhan City $\left(114.3^{\circ} \mathrm{E}\right.$, $30.8^{\circ} \mathrm{N}$ ), Hubei Province, China. Direct fluorescent
C Biomed Central 
antibody test (dFAT) of the specimen was performed as previously described [21-23]. Normal buffalo brain samples were used as a negative control. RABV isolation by mouse inoculation test was performed as described previously [24,25].

The total RNA from buffalo brain was extracted with Trizol reagent (Invitrogen) according to the manufacturer's instructions. Primer design and reverse-transcriptase polymerase chain reaction (RT-PCR) of the G gene were performed as described previously [17]. RT-PCR products were visualized under UV light after electrophoresis on $1 \%$ agarose gels containing ethidium bromide. The amplified products were purified with a QIAquick PCR gel extraction kit (QIAGEN) according to the manufacturer's protocol. The sequencing was carried out in an Applied Biosystems 3730 DNA automated sequencer. After the raw sequences were edited by ClustalX Version 1.82 [26], 1575 nt sequences of the G gene were obtained and submitted to GenBank.

The phylogenetic tree based on the deduced amino acid sequences was constructed by using the neighbor-joining method with 1,000 bootstrap replicates using MEGA version 4.0 software [27], based on the complete sequence of the RABV G gene from 10 different species of animal (Table 1 ). Bootstrap values $>70 \%$ were considered significant [28]. Genetic distance analysis for the $G$ gene was conducted with PHYLIP version 3.63 software [29]. Glycoprotein nucleotide sequences from different animals were identified, translated into amino acid sequences, edited, and pair aligned using BioEdit software [27]. Multiple alignments were performed by ClustalX software [26].

\section{Conclusion}

dFAT indicated the presence of RABV antigen in the brain specimens from the buffalo with suspected rabies (Figure 1A), whereas normal buffalo brain did not (Figure 1B). The expected size of the $G$ gene fragment was obtained from the suspected buffalo brain by RTPCR (data not shown). RABV from buffalo was isolated successfully in suckling mice (data not shown), and the RABV was named Hubei070308 strain. The positive result was supported by $\mathrm{G}$ gene sequencing, and the sequences were submitted to GenBank under the accession number EF643518.

The G gene sequence, together with reference sequences from seven countries and 10 species of animals were aligned (Table 1). We showed that the G gene of RABV had relative territorial specificity but not species specificity (Figure 2). The genetic relationship of the RABV in this study was differed greatly from PG(AY009097) that was used as a vaccine strain in China in 1931. Compared with 18 other RABV strains, Hubei070308 shared 85.0-99.8\% sequence identity at the amino acid level (data not shown). We demonstrated that Hubei070308 strain was close to the cattle strain FJ602451 and the human strain DQ849063, which belong to Chinese group I [17], but it was far from coyote strain U52946, which was isolated in 1996 in the United States (Figure 2).

Table 1 Detailed information of the G gene used in the present study

\begin{tabular}{|c|c|c|c|c|}
\hline No. & Virus strains & $\begin{array}{l}\text { Country and } \\
\text { year of isolation }\end{array}$ & Accession Number & Host species \\
\hline 1 & NNV-RAB-H & India 2007 & EF437215 & homo sapiens \\
\hline 2 & ZAMRAV51/00 & Zambia 2000 & AB285215 & dog \\
\hline 3 & HN06 & China 2005 & DQ849062 & dog \\
\hline 4 & FY3 & China 2004 & DQ849046 & dog \\
\hline 5 & THA1-HM & Thailand 1983 & AF325488 & human \\
\hline 6 & MAL1-HM & Malaysia 1985 & AF325487 & human \\
\hline 7 & $\mathrm{CHI} 1-\mathrm{BK}$ & China 1986 & AF325471 & deer \\
\hline 8 & COSRV & USA 1996 & U52947 & coyote \\
\hline 9 & SHBRV & USA 1996 & U52946 & bat \\
\hline 10 & 90RABN5850 & Canada 2001 & U11754 & vulpes \\
\hline 11 & PA R89 & Canada 2001 & U27217 & Procyon \\
\hline 12 & 92RBG1741 & Canada 2001 & AF344305 & skunk \\
\hline 13 & Hubei070308 & China 2007 & EF643518 & buffalo \\
\hline 14 & PG & China 1931 & AY009097 & dog(Vaccine Strain) \\
\hline 15 & QC & China 2006 & DQ849063 & human \\
\hline 16 & HNC & China 2007 & FJ602451 & cattle \\
\hline 17 & LuoH & China 2007 & FJ602453 & Homo sapiens \\
\hline 18 & 92RBGL0867 & Canada 1992 & AF344307 & Striped skunk \\
\hline 19 & NY516 & USA 1995 & U27214 & raccoon \\
\hline
\end{tabular}




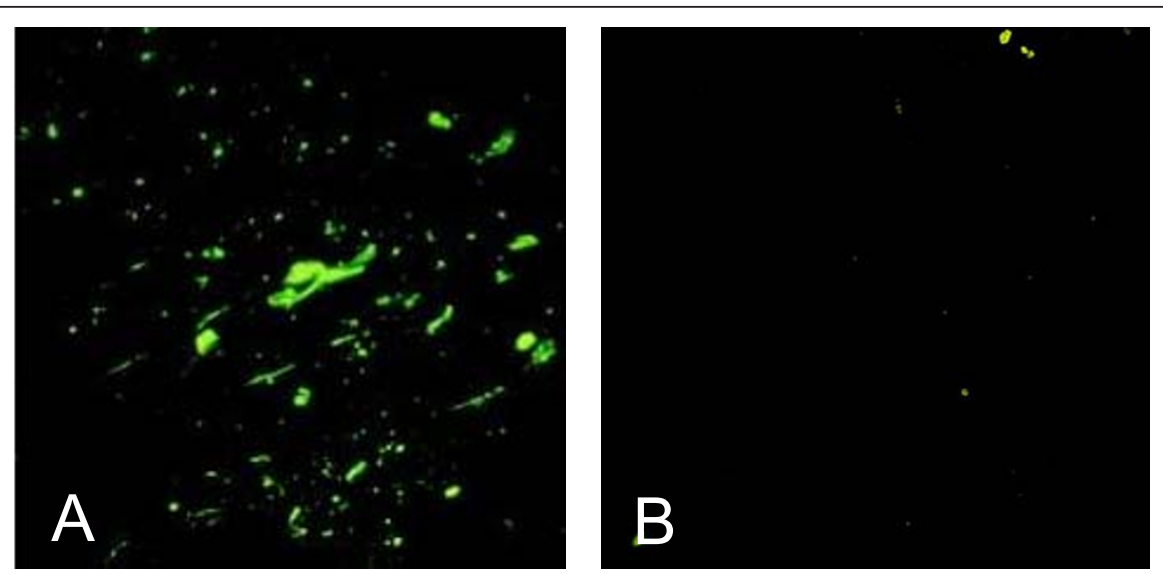

Figure 1 Results of dFAT of specimens from brain of buffalo with suspected rabies. (A) suspected buffalo brain sample; (B) normal buffalo brain sample.

Additional File 1, Figure S1 shows that the amino acid changes were mainly focused on the transmembrane areas (aa 440-461), inner-membrane zone (aa 462-505) and signal peptide range of mature RABV glycoprotein. Glycoprotein sequences of Hubei070308 were identical to HNC (FJ602451) that was isolated from cattle in 2007. However, there were many amino acid substitutions when it was compared with RABVs from other animals such as skunk, dog, human, bat and deer. The linear epitope (aa 14-19) at antigenic site II and the minor site between aa 342 and 343 were highly conserved, which was consistent with the findings of Meng et al. [17]. Among all the RABVs, SHBRV strain that was isolated from bats was the most variable at the amino acid level. Many different animals can be infected by RABV [2], and cases of transmission from bats to humans [30], dogs to humans [17] and even dogs to pigs [31] have been reported. For a virus shed by one host to infect another, it must break through entry barriers (e.g., epithelium, mucus, and alveolar macrophages) and find its way to tissues in which it can replicate [32].

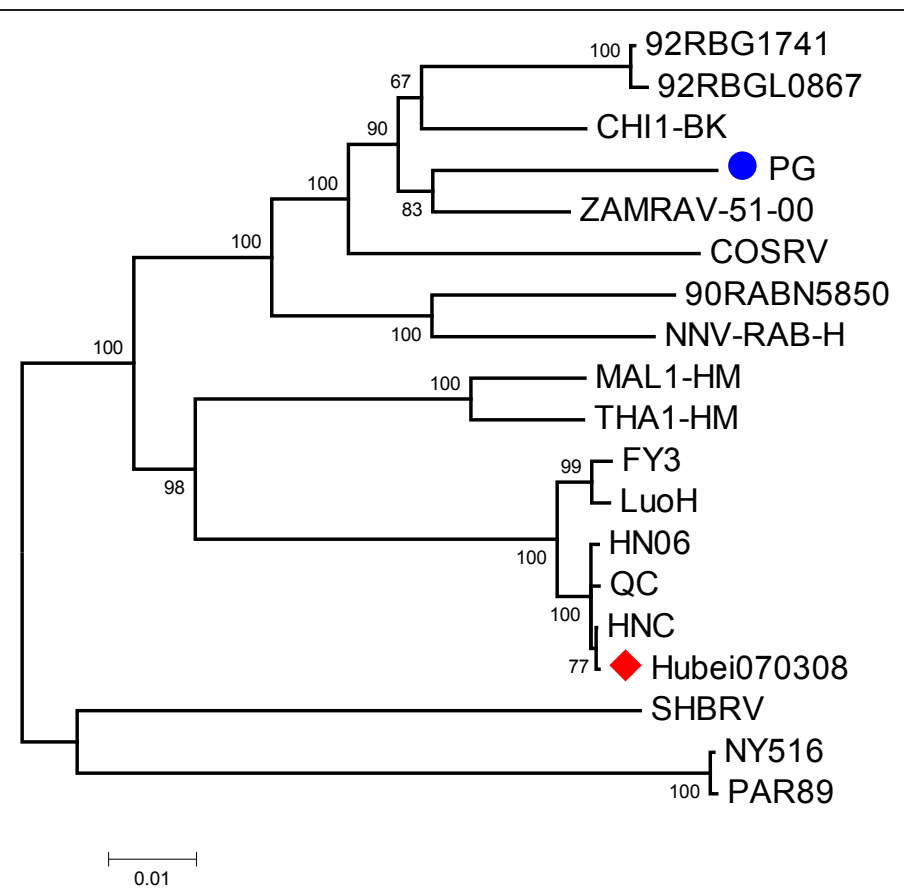

Figure 2 Phylogenetic analysis based on deduced amino acid sequence of complete $\mathbf{G}$ gene. The phylogenetic tree was constructed by the neighbor-joining algorithm using MEGA version 4.0, and bootstrap analysis was performed with 1,000 trials. All sequences were collected from GenBank. The red spot indicates Hubei070308 that was isolated in the present study. The blue spot indicates the 1931 RABV vaccine strain. 
It has been reported that several amino acids in the RABV glycoprotein are responsible for pathogenicity $[33,34]$. Therefore, RABV glycoprotein is the best target protein to study virus-host interaction, or it may be the main protein that is responsible for breakthrough of the species barrier. In the present study, many amino acid substitutions in $G$ protein were found among RABVs that were isolated from different animal species, or from the same species distributed in different geographic regions. These substituted amino acids may explain why RABV can break through the host barrier to infect one species of animal from another. This hypothesis needs to be confirmed by further experiments.

\section{Additional material}

Additional file 1: Figure S1. Comparative analysis of $\mathrm{G}$ gene amino acid with other RABVs isolated from different animals. Dots

represent identity among all sequences. Arrows mark the range of the signal peptide, antigenic site, linear epitope and endo-domain. Transmembrane (TM) domain was framed. SP: signal peptides; ENDO: endodomain; AS2: antigenic site II; AS3: antigenic site III; LE: linear epitope.

\section{List of abbreviations}

dFAT: direct fluorescent antibody test (dFAT); G: Glycoprotein; RABV: rabies virus; RT-RCR: reverse-transcriptase polymerase chain reaction.

\section{Acknowledgements}

We are grateful to Gelin Xu and Jiaxin Yan in Wuhan Institute of Biological Products for their ideas and assistance. Financial support was provided by National Modern Meat Caprine Industrial Technology System (nycytx-39) and State Key Laboratory of Agricultural Microbiology opening fund (AMLKF201005) of HZAU. The authors would like to thank the journal editors and anonymous reviewers for their editing and revision the manuscript.

\section{Author details}

${ }^{1}$ State Key Laboratory of Veterinary Etiological Biology, National Foot-andMouth Disease Reference Laboratory, Key Laboratory of Animal Virology of Ministry of Agriculture, Lanzhou Veterinary Research Institute of Chinese Academy of Agriculture Science, Xujiaping No.1, Yanchangpu, Lanzhou, Gansu, 730046, PR China. ${ }^{2}$ State Key Laboratory of Agricultural Microbiology, College of Veterinary Medicine, Huazhong Agricultural University, Wuhan 430070, Hubei, PR China.

\section{Authors' contributions}

BW was the leader of the project. KZ carried out most of the studies and drafted the manuscript. ZX and MX amplified the complete $G$ gene. $H C$ and $J G$ provided consultation and preparation of the final report. All authors read and approved the final manuscript.

\section{Competing interests}

The authors declare that they have no competing interests.

Received: 19 January 2011 Accepted: 6 March 2011

Published: 6 March 2011

\section{References}

1. Mayo MA, Haenni AL: Report from the 36th and the 37th meetings of the Executive Committee of the International Committee on Taxonomy of Viruses. Arch Virol 2006, 151:1031-1037.

2. Cisterna D, Bonaventura R, Caillou S, Pozo O, Andreau ML, Fontana LD, Echegoyen C, de Mattos C, de Mattos C, Russo S, et al: Antigenic and molecular characterization of rabies virus in Argentina. Virus Res 2005 109:139-147.

3. Knobel DL, Cleaveland S, Coleman PG, Fevre EM, Meltzer MI, Miranda ME, Shaw A, Zinsstag J, Meslin FX: Re-evaluating the burden of rabies in Africa and Asia. Bull World Health Organ 2005, 83:360-368.

4. Sugiyama M, Ito N: Control of rabies: epidemiology of rabies in Asia and development of new-generation vaccines for rabies. Comp Immunol Microbiol Infect Dis 2007, 30:273-286.

5. Zhang YZ, Xiong CL, Xiao DL, Jiang RJ, Wang ZX, Zhang LZ, Fu ZF: Human rabies in China. Emerg Infect Dis 2005, 11:1983-1984.

6. Song M, Tang Q, Wang DM, Mo ZJ, Guo SH, Li H, Tao XY, Rupprecht CE, Feng ZJ, Liang GD: Epidemiological investigations of human rabies in China. BMC Infect Dis 2009, 9:210.

7. Bourhy H, Kissi B, Tordo N: Molecular diversity of the Lyssavirus genus. Virology 1993, 194:70-81.

8. Shimizu K, Ito N, Mita T, Yamada K, Hosokawa-Muto J, Sugiyama M, Minamoto N: Involvement of nucleoprotein, phosphoprotein, and matrix protein genes of rabies virus in virulence for adult mice. Virus Res 2007, 123:154-160.

9. Wu X, Franka R, Velasco-Villa A, Rupprecht CE: Are all lyssavirus genes equal for phylogenetic analyses? Virus Res 2007, 129:91-103.

10. Morimoto K, Hooper DC, Spitsin S, Koprowski H, Dietzschold B: Pathogenicity of different rabies virus variants inversely correlates with apoptosis and rabies virus glycoprotein expression in infected primary neuron cultures. J Virol 1999, 73:510-518.

11. Faber M, Faber ML, Papaneri A, Bette M, Weihe E, Dietzschold B, Schnell MJ: A single amino acid change in rabies virus glycoprotein increases virus spread and enhances virus pathogenicity. J Virol 2005, 79:14141-14148.

12. Badrane H, Bahloul C, Perrin P, Tordo N: Evidence of two Lyssavirus phylogroups with distinct pathogenicity and immunogenicity. J Virol 2001, 75:3268-3276.

13. Durrer P, Gaudin Y, Ruigrok RW, Graf R, Brunner J: Photolabeling identifies a putative fusion domain in the envelope glycoprotein of rabies and vesicular stomatitis viruses. J Biol Chem 1995, 270:17575-17581.

14. Thoulouze MI, Lafage M, Schachner M, Hartmann U, Cremer H, Lafon M: The neural cell adhesion molecule is a receptor for rabies virus. I Virol 1998, 72:7181-7190.

15. Tuffereau C, Benejean J, Blondel D, Kieffer B, Flamand A: Low-affinity nerve-growth factor receptor (P75NTR) can serve as a receptor for rabies virus. Embo J 1998, 17:7250-7259.

16. Zhang S, Zhao J, Liu Y, Fooks AR, Zhang F, Hu R: Characterization of a rabies virus isolate from a ferret badger (Melogale moschata) with unique molecular differences in glycoprotein antigenic site III. Virus Res 2010, 149:143-151.

17. Meng SL, Yan JX, Xu GL, Nadin-Davis SA, Ming PG, Liu SY, Wu J, Ming HT, Zhu FC, Zhou DJ, et al: A molecular epidemiological study targeting the glycoprotein gene of rabies virus isolates from China. Virus Res 2007, 124:125-138

18. Carnieli P Jr, Castilho JG, Fahl Wde O, Veras NM, Carrieri ML, Kotait I: Molecular characterization of Rabies Virus isolates from dogs and crabeating foxes in Northeastern Brazil. Virus Res 2009, 141:81-89.

19. Feyssaguet M, Dacheux L, Audry L, Compoint A, Morize JL, Blanchard I, Bourhy H: Multicenter comparative study of a new ELISA, PLATELIA RABIES II, for the detection and titration of anti-rabies glycoprotein antibodies and comparison with the rapid fluorescent focus inhibition test (RFFIT) on human samples from vaccinated and non-vaccinated people. Vaccine 2007, 25:2244-2251.

20. Flamand A, Wiktor TJ, Koprowski H: Use of hybridoma monoclonal antibodies in the detection of antigenic differences between rabies and rabies-related virus proteins. II. The glycoprotein. J Gen Virol 1980, 48:105-109.

21. Rudd RJ, Smith JS, Yager PA, Orciari LA, Trimarchi CV: A need for standardized rabies-virus diagnostic procedures: effect of cover-glass mountant on the reliability of antigen detection by the fluorescent antibody test. Virus Res 2005, 111:83-88,

22. Tepsumethanon V, Lumlertdacha B, Mitmoonpitak C, Fagen R, Wilde H: Fluorescent antibody test for rabies: prospective study of 8,987 brains. Clin Infect Dis 1997, 25:1459-1461.

23. Bingham J, van der Merwe M: Distribution of rabies antigen in infected brain material: determining the reliability of different regions of the 
brain for the rabies fluorescent antibody test. J Virol Methods 2002, 101:85-94.

24. Chhabra M, Bhardwaj M, Ichhpujani RL, Lal S: Comparative evaluation of commonly used laboratory tests for post-mortem diagnosis of rabies. Indian J Pathol Microbiol 2005, 48:190-193.

25. Chhabra M, Mittal V, Jaiswal R, Malik S, Gupta M, Lal S: Development and evaluation of an in vitro isolation of street rabies virus in mouse neuroblastoma cells as compared to conventional tests used for diagnosis of rabies. Indian J Med Microbiol 2007, 25:263-266.

26. Thompson JD, Gibson TJ, Plewniak F, Jeanmougin F, Higgins DG: The CLUSTAL_X windows interface: flexible strategies for multiple sequence alignment aided by quality analysis tools. Nucleic Acids Res 1997, 25:4876-4882.

27. Tamura K, Dudley J, Nei M, Kumar S: MEGA4: Molecular Evolutionary Genetics Analysis (MEGA) software version 4.0. Mol Biol Evol 2007, 24:1596-1599.

28. Beasley WH, Deshea L, Toothaker LE, Mendoza JL, Bard DE, Rodgers JL: Bootstrapping to test for nonzero population correlation coefficients using univariate sampling. Psychol Methods 2007, 12:414-433.

29. Retief JD: Phylogenetic analysis using PHYLIP. Methods Mol Biol 2000, 132:243-258

30. da Rosa ES, Kotait I, Barbosa TF, Carrieri ML, Brandao PE, Pinheiro AS, Begot AL, Wada MY, de Oliveira RC, Grisard EC, et al: Bat-transmitted human rabies outbreaks, Brazilian Amazon. Emerg Infect Dis 2006, 12:1197-1202

31. Jiang Y, Yu X, Wang L, Lu Z, Liu H, Xuan H, Hu Z, Tu C: An outbreak of pig rabies in Hunan province, China. Epidemiol Infect 2008, 136:504-508.

32. Kuiken T, Holmes EC, McCauley J, Rimmelzwaan GF, Williams CS, Grenfell BT: Host species barriers to influenza virus infections. Science 2006, 312:394-397.

33. Takayama-lto M, Ito N, Yamada K, Sugiyama M, Minamoto N: Multiple amino acids in the glycoprotein of rabies virus are responsible for pathogenicity in adult mice. Virus Res 2006, 115:169-175.

34. Takayama-Ito M, Ito N, Yamada K, Minamoto N, Sugiyama M: Region at amino acids 164 to 303 of the rabies virus glycoprotein plays an important role in pathogenicity for adult mice. J Neurovirol 2004, 10:131-135.

doi:10.1186/1743-422X-8-101

Cite this article as: Zhang et al: Diagnosis and molecular characterization of rabies virus from a buffalo in China: a case report. Virology Journal 2011 8:101.

\section{Submit your next manuscript to BioMed Central and take full advantage of:}

- Convenient online submission

- Thorough peer review

- No space constraints or color figure charges

- Immediate publication on acceptance

- Inclusion in PubMed, CAS, Scopus and Google Scholar

- Research which is freely available for redistribution

Submit your manuscript at www.biomedcentral.com/submit
Biomed Central 